THE IMAGE OF CHRIST IN RUSSIAN LITERATURE 



\section{THE IMAGE OF CHRIST IN RUSSIAN LITERATURE}

Dostoevsky, Tolstoy, Bulgakov, Pasternak

JOHN GIVENS 
Northern Illinois University Press, DeKalb 60115

(c) 2018 by Northern Illinois University Press

All rights reserved

$\begin{array}{llllllllll}27 & 26 & 25 & 24 & 23 & 22 & 21 & 20 & 19 & 18\end{array}$

2345

978-0-87580-779-9 (case)

978-1-60909-238-2 (e-book)

Book and cover design by Yuni Dorr

Library of Congress Cataloging-in-Publication Data

is available online at http://catalog.loc.gov 
FOR ANNA AND WILL

IN MEMORIAM MARIAN AND CALVIN SCHWENK 
